ECONOMICS

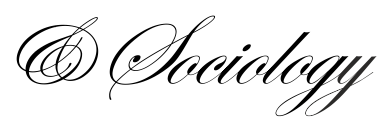

\author{
Romualdas Ginevičius, \\ Vilnius Gediminas Technical \\ University, \\ Vilnius, Lithuania, \\ E-mail: \\ romualdas.ginevicius@vgtu.lt
}

Dainora Gedvilaitè,

Vilnius Gediminas Technical

University,

Vilnius, Lithuania,

E-mail:dainora.gedvilaite@vgtu.lt

\author{
Andrius Stasiukynas, \\ Vilnius Gediminas Technical \\ University, \\ Vilnius, Lithuania, \\ E-mail:andrius@snowarena.lt
}

Martin Čepel,

Paneuropean University in

Bratislava,

Bratislava, Slovak Republic,

E-mail:cepel@benzinol.com

Received: October, 2017

1st Revision: January, 2018

Accepted: February, 2018

DOI: $10.14254 / 2071-$

789X.2018/11-1/1

JEL Classification: O1, Q01.
Ginevičius, R., Gedvilaitė, D., Stasiukynas, A., Čepel, M. (2018). Integrated Assessment of the Socioeconomic Systems' Development. Economics and Sociology, 11(1), 11-21. doi:10.14254/2071-789X.2018/11-1/1

\section{INTEGRATED ASSESSMENT OF THE SOCIOECONOMIC SYSTEMS' DEVELOPMENT}

\begin{abstract}
A permanent property applicable to every socioeconomic system (SES) is its development. SES development is an integrated process with two sides that can be distinguished, i.e. quantitative and qualitative ones. The quantitative side reflects its static aspect, i.e. the state of the development at a certain point in time. The qualitative side of development reflects its dynamics, i.e. the scope of development changes. In order to make an integrated assessment of the standing of SES development, both these aspects above have to be assessed in a quantitative manner and be further combined into one generalised value. These days, assessment of the standing of SES development is limited to evaluation of the achieved level only, i.e. its quantitative assessment. Due to the fact that all socioeconomic systems are always large and complex systems, they tend to have a multitude of aspects. The indicators that reflect such aspects form a system thereof. It is thus the basis for further multicriteria assessment of the development state. In order to reduce the number of indicators to be assessed simultaneously so that experts could establish the weights thereof in a sufficiently accurate manner, a hierarchically structured system of indicators is developed and presented here. Following this methodology, the level of economic development across Lithuanian regions has been determined. When the scope of development changes was established on that basis, the integrated indicator of the regional development state was calculated following the proposed formula. On the basis of the correlation-regression analysis, it has been determined that the scope of development changes is larger in the regions with lower level of development achieved.
\end{abstract}

Keywords: socioeconomic systems (SES), SES development, multicriteria assessment, integrated assessment, economic development

\title{
Introduction
}

In order to assess the SES development adequately, this phenomenon needs to be examined in detail. The word "development" as such implies there is a certain process. In Latin 
this word means acceleration, expedition, a move forward etc. In other words, it is a set of certain consistent actions directed towards a specific result (Dictionary of Foreign Words). This explanation leads us to two important aspects. First, it is an action or a movement; second, this movement relates to a specific result. These two aspects vary in terms of their nature. The first one implies dynamics, whereas the second one is more static in nature. Statics here means a certain state of a SES, whereas dynamics implies changes in this state. The state of a SES is the level of its development at a certain point in time. Hence, it reflects the quantitative side of development as a process. On the other hand, changes in the state (of SES) imply the scope of changes; thus it portrays the qualitative side of development as a process.

The two aspects of SES development are inseparable. High level of development achieved has its positive effect on the speed of development changes; likewise, high level of development changes positively affects further development. In this uninterrupted process SES can have a variety of situations in terms of both the level of development achieved and the development changes (Fig. 1).

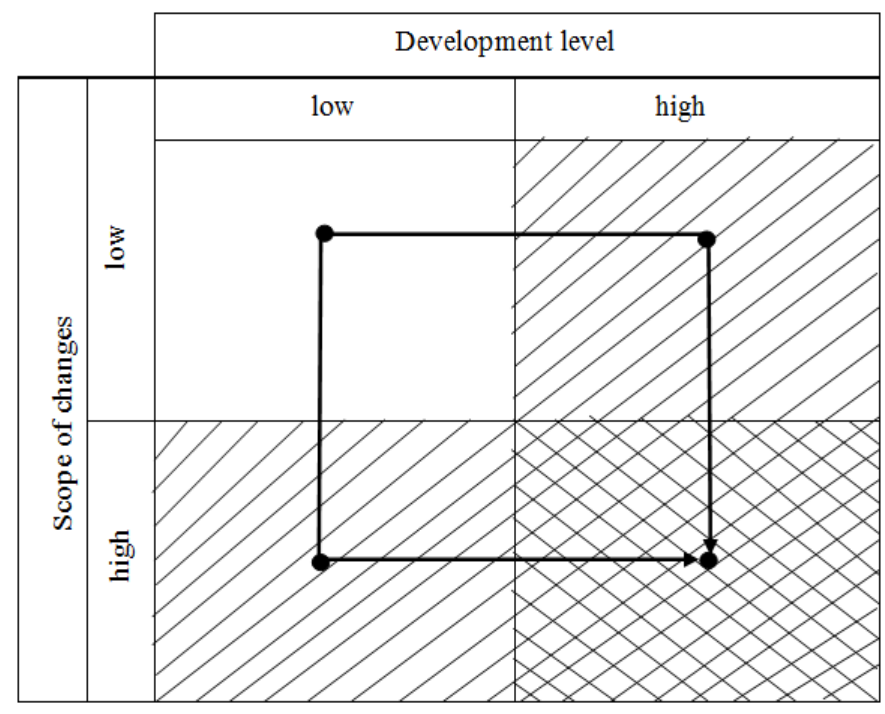

Fig. 1. Situations of SES development Source: own data.

It is evident from Fig. 1 that both the level of development and the speed of development changes of a SES can be low, i.e. a system can be stagnating. On the other hand, should it increase the speed of development changes, it will achieve higher level of development thereby.

To sum up, we can state that, first, a quantitative side of SES development, which is reflected in the level of development, has to be distinguished from the qualitative side, which is portrayed by the scope of development changes. Secondly, in order to carry out an integrated assessment of the state of SES development, both of the above aspects need to be combined into one generalised value. Therefore, the primary model for assessing the state of SES development would look as follows (Fig. 2). 


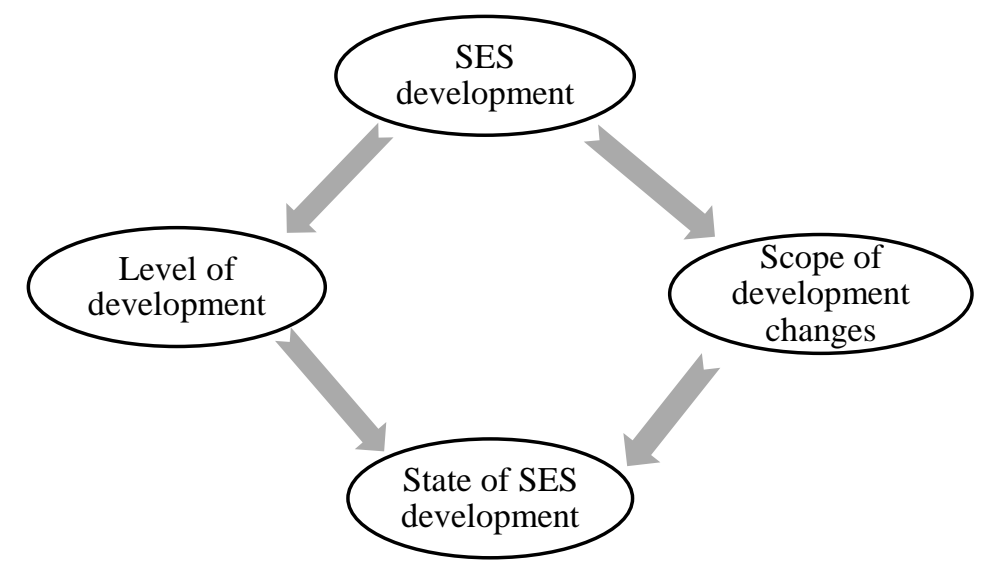

Fig. 2. Primary model for assessing the state of SES development Source: own data.

To offer a methodology for assessing the state of SES development, the analysis of the current standing needs to be carried out beforehand.

\section{Existing methods for assessing the standing of SES development}

The current situation can be described using three characteristics: first, growing complexity; second, increasing dynamics; and third, growing information flows. All of the above increase the uncertainty, hence, the likelihood of having wrong decisions made and the losses incurred in connection therewith (Fig. 3).

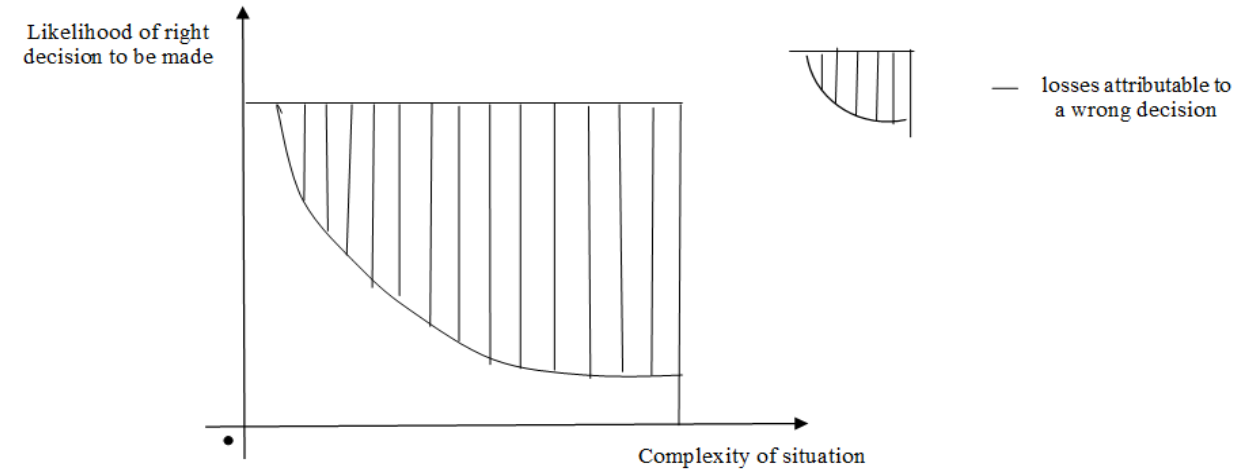

Fig. 3. Relation between the uncertainty of a situation and decision making Source: own data.

The question is how the situations that we face can be simplified. The system theory offers a way out as it helps reflect complex, controversial and ambiguous reality in a simplified (yet sufficiently adequate) way, thus reducing the complexity of problems to be solved and increasing the likelihood of right decisions being made at the same time and any potential losses resulting from wrong decisions being reduced.

The system theory helps carry out a systematic analysis of phenomena, i.e. analyse them in line with the interlinks of their components. 
The advantage of this theory lies in the fact that it allows examining complex phenomena significantly deeper (as all of them essentially fall under socioeconomic systems), thus knowing them better at the same time. A plethora of researches designed to examine a variety of aspects of the systems can be found. In terms of this, the question is what the purpose of getting to know the systems is. Long-standing experience of human activities shows that the purpose of getting to know the SES is the search for opportunities to change the standing there of in a focused manner (Ginevičius, 2009).

A system can only be managed in a focused manner if it is possible to assess the standing thereof. It can be expressed both in a qualitative and a quantitative manner. The qualitative assessment of the standing is limited because this case makes it impossible to compare the cost system aimed at improving the functioning of a system with the scope of improvements achieved. Therefore, two methods for a quantitative assessment of complex phenomena, which manifest in a variety of aspects in reality, have been developed in the recent years (Ginevičius et al., 2015, 2016; Mardani et al., 2015; Zhou et al., 2007; Zavadskas et al., 2014).

The basis for this was the division of the systems into real (material) and theoretical (abstract) ones. The former include physical and live objects, whereas the latter, theories of hypotheses, formalised models, etc.

Such a division of the systems existent in the nature is very important in terms of qualitative assessment of their standing. This becomes apparent when analysing the interlink between the systems of these two types. Processes part of material systems give rise to information flows which get formalised and turn into indicators. The aggregate there of becomes formalised models of real systems. Hence, a formalised model of a real system is a system of indicators that reflects the functioning thereof.

SES fall under large and complex systems; thus they are portrayed by a large number of indicators of different nature. In order to assess the standing of such system with the help thereof, all of them have to be combined into one generalised value. This leads to the property of quantitative assessment of the SES standing being multicriteria and the fact that multicriteria assessment methods are fit for the purpose.

On the other hand, to enjoy this opportunity, certain procedures have to be carried out in respect of the indicators. They have expressed in different dimensions; hence, to combine them into one generalised value they must be turned into comparable ones. This is carried out through normalising the values of indicators.

The normalisation method depends on the purpose of a multicriteria assessment. If the objective is to determine the ranking of SES options (for instance, rank the regions across the country by their social-economic development), it looks as follows:

$$
\tilde{q}_{i j}=\frac{q_{i j}}{\sum_{i=1}^{n} q_{i j}}
$$

where $\tilde{q}_{i j}$-the normalised value of $\mathrm{i}^{\text {th }}$ indicator of the $\mathrm{j}^{\text {th }}$ option; ${ }^{q_{i j}}-$ the value of $\mathrm{i}^{\text {th }}$ indicator of the $\mathrm{j}^{\text {th }}$ option; $\mathrm{n}$ - the number of indicators $(i=\overline{1, n})$.

If the normalisation is carried out in line with formula (1), the value of $\mathrm{i}^{\text {th }}$ indicator of the $\mathrm{j}^{\mathrm{t}}$ option flows from the values of the same indicator in respect of other options.

Provided the objective of a multicriteria assessment is to assess the standing of development of an individual SES, the normalised values of indicators must be determined outside of the context in terms of the values of the same indicator in respect of other options. In such event, the normalisation is carried out in the following way (Ginevičius et al., 2015): 


$$
\tilde{q}_{i}=\frac{q_{i F}}{q_{\max i F}}
$$

where $q_{\text {maxiF }}$ - the maximum possible value of the $\mathrm{i}^{\text {th }}$ indicator.

Normalisation of the indicator values based on formula (2) automatically turns all of them into maximising ones where the higher value of the indicator implies better standing of a SES.

A multicriteria assessment of the economic development across Lithuanian regions has been carried out based on the afore-mentioned methodology. It has been performed using the SAW method (Hwang, Yoon, 1981):

$$
K_{p}=\sum_{i=1}^{n} w_{i} \tilde{q}_{i}
$$

where $K_{p}$ - the value of a multicriteria assessment using the SAW method; $w_{i}$ - the weight of the $\mathrm{i}^{\text {th }}$ indicator.

Such activities that generate a material product fell under the economic development. On that basis, the indicators that reflect, for instance, foreign and domestic trade, which disposes of the products generated in economic activities, were excluded.

A hierarchical system of indicators has been developed to reduce the number of indicators to be assessed simultaneously. This is necessary because experts are able to assess the weight of only a limited number of indicators (Ginevičius, 2009; Ginevičius et al., 2015, 2016). Based on the available statistical information, it has been determined that 19 indicators give an indication of the regional economic development. What is more, they are different in terms of their nature, i.e. reflect different areas of economic development (industry, construction and the like). A single expert cannot be competent in all areas. Therefore, in the course of structuring the system of indicators, two principles were followed: first, related indicators were included in one category; second, it was followed that a single category does not contain more than $10-12$ indicators. Following the above, all indicators that portray regional economic development were grouped into two units with each of them covering a characteristic area, i.e. industry, construction, agriculture and transport (Fig. 4).

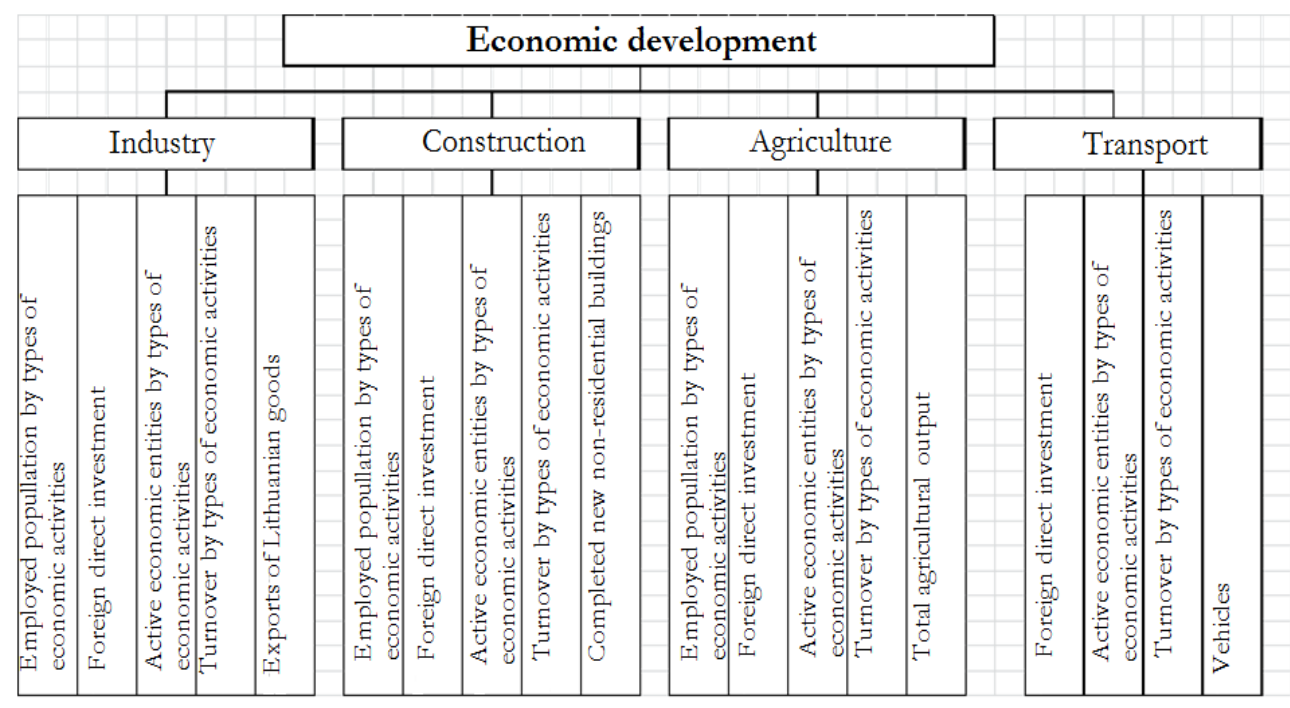

Fig. 4. Hierarchical system of indicators of economic development across Lithuanian regions Source: own compilation. 
Based on the hierarchical system of indicators (Fig. 4), the weights of indicators determined using the expert method and the normalised values thereof, a multicriteria assessment of economic development across Lithuanian regions has been carried out using the SAW method (3). The results of calculations have been provided in Table 1.

Table 1. Results of a multicriteria assessment of economic development across Lithuanian regions using the SAW method

\begin{tabular}{cccccccc}
\hline \multirow{2}{*}{ No } & \multirow{2}{*}{ Regions } & \multicolumn{2}{c}{2010} & \multicolumn{2}{c}{2011} & \multicolumn{2}{c}{2012} \\
\cline { 2 - 7 } & & Value & Rank & Value & Rank & Value & Rank \\
\hline 1. & Vilnius & 0.3733 & 4 & 0.4244 & 9 & 0.3844 & 4 \\
\hline 2. & Kaunas & 0.3013 & 6 & 0.4384 & 7 & 0.3589 & 5 \\
\hline 3. & Klaipèda & 0.4396 & 2 & 0.5709 & 2 & 0.4794 & 1 \\
\hline 4. & Alytus & 0.2716 & 10 & 0.4447 & 5 & 0.3118 & 9 \\
\hline 5. & Marijampolè & 0.4542 & 1 & 0.4125 & 10 & 0.3369 & 7 \\
\hline 6. & Panevéžys & 0.2756 & 9 & 0.4437 & 6 & 0.3310 & 8 \\
\hline 7. & Šiauliai & 0.3530 & 5 & 0.4852 & 3 & 0.4417 & 3 \\
\hline 8. & Telšiai & 0.3855 & 3 & 0.5865 & 1 & 0.4658 & 2 \\
\hline 9. & Utena & 0.2895 & 7 & 0.4481 & 4 & 0.2952 & 10 \\
\hline 10. & Tauragé & 0.2838 & 8 & 0.4292 & 8 & 0.3423 & 6 \\
\hline
\end{tabular}

Source: own compilation.

The quantitative assessment of regional economic development provided for in Table 1 gives an indication of the first aspect of SES development, i.e. the level of development, that is, the standing of development at a given point in time. The other aspect, i.e. the scope of development changes, remains unassessed. The analysis of references demonstrates that other researches deal exclusively with the standing of development as opposed to any changes thereof (Čiegis et al., 2010; Golusin et al., 2011; Kondyli, 2010; Suna et al., 2015; Hak et al., 2012; Khalili, Duecker, 2013; Ibrahim et al., 2015; Leksin, Porfiryev, 2016; Boggia, Cortina, 2010; Babu, Datta, 2015; Pinter et al., 2012; Wallis et al., 2011; Espinoza et al., 2011; Fernandes, 2013; Zhou et al., 2007; Kevin, 2007; Ferrarini et al., 2001; Rajnoha, Lesníková, 2016; Lapinskienè et al., 2017). Therefore, it is possible to maintain that SES development gets assessed from a one-sided perspective only, i.e. in terms of its quantitative side. As mentioned above (Fig. 2), in order to make an integrated assessment of SES development, the scope of development changes has to be evaluated in a quantitative manner and this indicator has to be combined with the indicator of the standing of SES development.

The scope of SES development changes can be determined in a simple manner, i.e. by using a ratio of the standing of development achieved over a reporting period (subject to examination) to the same over a basic period.

$$
K_{p m}=\frac{K_{p n}}{K_{p b}}
$$

where $K_{p m}$ - the indicator of the scope of SES development changes; $K_{p n}$ - the standing of SES in a reporting period (subject to examination); $K_{p b}$ - the standing of SES in a basic period. 
To obtain the indicator of the standing of SES development, value $K_{p m}$ has to be combined with the indicator of the scope of development over a reporting period (subject to examination) $K_{p n}$. This can be carried out in the following way:

$$
K_{k p}=K_{p n} \times K_{p m}
$$

or

$$
K_{k p}=K_{p n} \times \frac{K_{p n}}{K_{p b}}=\frac{K_{p n^{2}}}{K_{p b}}
$$

where $K_{k p}$ - the integrated indicator of the standing of SES development.

The values of the standing of development across Lithuanian regions have been determined based on formulas (5) and (5a) and Table 1 (Table 2).

\begin{tabular}{|c|c|c|c|c|c|c|c|c|c|}
\hline \multirow{3}{*}{ No } & \multirow{3}{*}{ Regions } & \multicolumn{8}{|c|}{ Indicators } \\
\hline & & \multicolumn{2}{|c|}{$\begin{array}{c}\text { regional } \\
\text { development } \\
\text { level in a basic } \\
\text { period }\left(K_{p b}\right)\end{array}$} & \multicolumn{2}{|c|}{$\begin{array}{l}\text { regional development } \\
\text { level in a reporting } \\
\text { period (subject to } \\
\text { examination) }\left(K_{p n}\right)\end{array}$} & \multicolumn{2}{|c|}{$\begin{array}{c}\text { regional } \\
\text { development } \\
\text { changes }\left(K_{p m}\right)\end{array}$} & \multicolumn{2}{|c|}{$\begin{array}{c}\text { integrated indicator } \\
\text { of the standing of } \\
\text { regional } \\
\text { development }\left(K_{k p}\right)\end{array}$} \\
\hline & & value & rank & value & rank & value & rank & value & rank \\
\hline 1. & Vilnius & 0.3733 & 4 & 0.4244 & 9 & 1.14 & 9 & 0.4825 & 9 \\
\hline 2. & Kaunas & 0.3013 & 6 & 0.4384 & 7 & 1.46 & 6 & 0.6379 & 8 \\
\hline 3. & Klaipèda & 0.4396 & 2 & 0.5709 & 2 & 1.30 & 8 & 0.7414 & 2 \\
\hline 4. & Alytus & 0.2716 & 10 & 0.4447 & 5 & 1.64 & 1 & 0.7281 & 3 \\
\hline 5. & Marijampolè & 0.4542 & 1 & 0.4125 & 10 & 0.91 & 10 & 0.3746 & 10 \\
\hline 6. & Panevėžys & 0.2756 & 9 & 0.4437 & 6 & 1.61 & 2 & 0.7143 & 4 \\
\hline 7. & Šiauliai & 0.3530 & 5 & 0.4852 & 3 & 1.37 & 7 & 0.6669 & 6 \\
\hline 8. & Telšiai & 0.3855 & 3 & 0.5865 & 1 & 1.52 & 4 & 0.8923 & 1 \\
\hline 9. & Utena & 0.2845 & 7 & 0.4481 & 4 & 1.55 & 3 & 0.6936 & 5 \\
\hline 10. & Tauragè & 0.2838 & 8 & 0.4292 & 8 & 1.51 & 5 & 0.6493 & 7 \\
\hline
\end{tabular}

Table 2. Calculation results for the standing of development across Lithuanian regions

Source: own compilation.

The differences between the assessment of the standing of SES development in line with the scope of development changes and the same in disregard thereof are clearly evident in Table 3.

Table 3. Standing of development across Lithuanian regions in line with the scope of development changes and the same in disregard thereof

\begin{tabular}{clccc}
\hline \multirow{2}{*}{ No } & \multirow{2}{*}{ Regions } & \multicolumn{3}{c}{ Change in the standing of development, percentage } \\
\cline { 3 - 5 } & & $\begin{array}{c}\text { in disregard of the } \\
\text { scope of changes }\end{array}$ & $\begin{array}{c}\text { in line with the } \\
\text { scope of changes }\end{array}$ & ratio \\
\hline 1 & 2 & 3 & 4 & 5 \\
\hline 1. & Vilnius & 13.7 & 29.3 & 2.14 \\
\hline 2. & Kaunas & 45.5 & 68.6 & 2.45 \\
\hline 3. & Klaipéda & 29.9 & 168.1 & 2.29 \\
\hline 4. & Alytus & 63.7 & -17.5 & -1.92 \\
\hline 5. & Marijampole & -9.1 & & \\
\hline
\end{tabular}




\begin{tabular}{rlccc}
\hline 1 & \multicolumn{1}{c}{2} & 3 & 4 & 5 \\
\hline 6. & Panevėžys & 61.0 & 159.2 & 2.61 \\
\hline 7. & Šiauliai & 37.4 & 88.9 & 2.38 \\
\hline 8. & Telšiai & 52.1 & 131.5 & 2.52 \\
\hline 9. & Utena & 54.8 & 139.6 & 2.55 \\
\hline 10. & Tauragé & 51.2 & 128.8 & 2.52 \\
\hline
\end{tabular}

Source: own compilation.

It is evident from Table 3 that the differences between the assessment of the standing of SES development in line with the scope of development changes and the same in disregard thereof vary within a very wide range in terms of individual regions; also, the ratio is above two in almost all cases. This speaks of the fact that in the course of assessment of the standing of SES development it is necessary to take into account not only the scope of development, but also the scope of development changes.

When making an integrated assessment of SES development, it is also important to determine the cross-impact of the development level achieved and the scope of its changes. In other words, it has to be determined to what extent the development level achieved affects the scope of development changes, i.e. the dependence needs to be established.

$$
K_{p m}=f\left(K_{p n}\right)
$$

The dependence (6) can be realised on the basis of correlation-regression analysis. When a correlation field is generated pursuant to Table 2, it is apparent that the above dependence is inverse, i.e. as the level of development increases, the scope of development changes decreases (Ill. 5). Two regions of the country have been excluded from the correlation field for being noncharacteristic, i.e. Vilnius and Marijampolè.

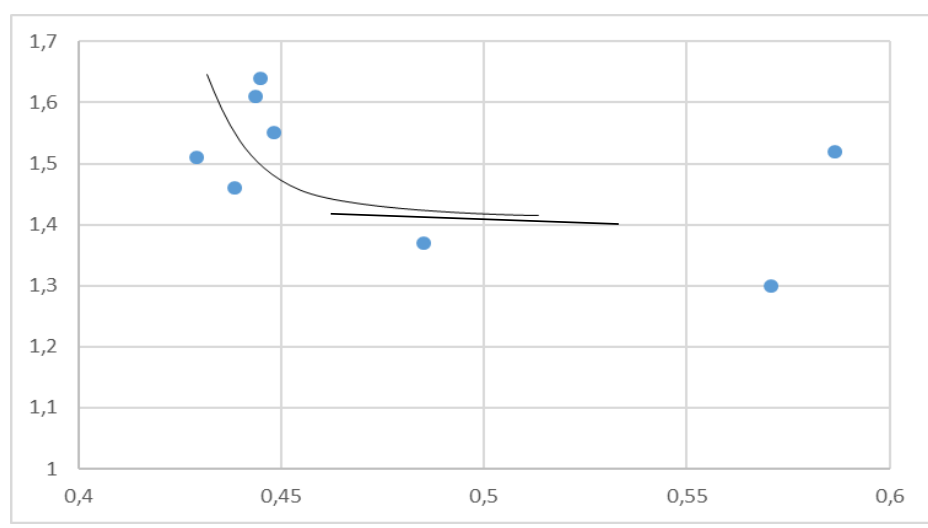

Fig. 5. Dependence of the scope of SES development changes on the development level achieved

Source: own data.

It is evident from Fig. 5 that the dependence can either be linear or parabolic. Paired correlation-regression analysis has shown that the dependence is better expressed using a parabola. The coefficient of the strength of relationship is $r=-0.52$, this suggests a relatively strong relationship. The regression equation is as follows: 


$$
K_{p m}=1,9505-0,9472 K_{p n}
$$

The correlation-regression analysis of the interlink between the level of economic development across Lithuanian regions and the scope of development changes has demonstrated that lower level of SES development mobilises and motivates more backward regions to increase the speed of development. Regional policies, which aim to reduce the development differences between individual regions, implemented by the government also help this. What is more, better developed regions face increasing difficulties in creating and exploiting new essential opportunities for further development. Therefore, over time objective and subjective processes, which reduce the development gap between individual regions across the country, take place.

\section{Conclusion}

The development of socioeconomic systems is a complex and integrated process. Two key aspects can be distinguished within it, i.e. quantitative development and qualitative development. Quantitative development gives an indication of its level at a certain point in time, whereas qualitative development, the scope of changes thereof. In order to make an integrated assessment of the standing of SES development, these aspects have to be assessed in a quantitative manner and combined into one generalised value.

The analysis of scientific research designed to evaluate the SES development has shown that these days only one aspect of it gets assessed, i.e. the quantitative development. To this end, hierarchically structured systems of indicators are development and on the basis thereof a multicriteria assessment is carried out. That said, no research aimed at analysing the SES development changes practically exists. At the same time, there is also a lack of an integrated quantitative assessment of the standing of SES development that would combine both aspects of development.

Integrated assessment of the standing of economic development across Lithuanian regions using the proposed methodology has shown that the differences between the assessment of the standing of SES development in line with the scope of development changes and the same in disregard thereof make up 100-250 per cent. This speaks of the fact that in the course of the assessment of the standing of SES development it is necessary to take into account not only the scope of development, but also the scope of development changes.

The correlation-regression analysis of the cross-impact between the development level achieved by Lithuanian regions and the scope of changes thereof has demonstrated that a relatively close relationship exists between the two, i.e. an inverse relation, that is, as the level of development increases, the scope of development changes decreases. In addition, more rapid development changes happen in the regions with a lower level of development.

\section{References}

Babu, S., Datta, S. K. (2015). Revisiting the link between socio-economic development and environmental status indicators - focus on panel data. Environment. Development and Sustainability, 17(3), 567-586.

Boggia, A., Cortina, C. (2010). Measuring sustainable development using a multi-criteria model: A case study. Journal of Environmental Management, 91, 2301-2306.

Čiegis, R., Ramanauskienè, J., Šimanskienè, L. (2010). Lietuvos regionu darnaus vystymosi vertinimas. Klaipėda: Klaipėdos universiteto leidykla. 123 p. ISBN 978-9955-18-534-5. 
Dictionary of Foreign Words. Available from internet: http://www.zodynas2.lt/tarptautiniuzodziu/.

Espinosa, S., Angela, M., Walker, J. (2011). Complexity Approach to Sustainability, A: Theory And Application. London: Imperial College Press.

Fernandes, S. (2013). An empirical approach of the distinctive aspects for socioeconomic development. International Journal of Social Economics, 40(11), 956-970. http://dx.doi.org/10.1108/IJSE-02-2012-0031.

Ferrarini, A., Bodini, A., Becchi, M. (2001). Environmental quality and sustainability in the province of Reggio Emilia (Italy): using multi-criteria analysis to assess and compare municipal performance. Journal of Environmental Management, 63, 117-131.

Ginevičius, R. (2009). Socioekonominių sistemų būklès kiekybinio įvertinimo problematika. Verslas: teorija ir praktika, 10(2), 69-83.

Ginevičius, R., Gedvilaitè, D., Bruzgè, Š . (2015). Assessment of a country’s regional economic development on the basis of Estimation of a Single Process (ESP) method. Entrepreneurial business and economics review (EBER), 3(2), 141-153.

Ginevičius, R., Gedvilaite, D., Stasiukynas, A. (2016). Complex Assessment of the Ecological Development of the Country's Regions. The 9th International Scientific Conference "Business and Management 2016", May 12-13, Vilnius, Lithuania. Vilnius: Technika, 2016. ISSN 2029-4441, p. 1-9.

Golusin, M., Munitlak, O. I., Teodorovic. N. (2011). The review of the achieved degree of sustainable development in South Eastern Europe - The use of linear regression method. Renewable and Sustainable Energy Reviews, 15, 766-772.

Hak, T., Kovanda, J., Weinzettal, J. (2012). A method to assess the relevance of sustainability indicators: application to the indicator set of the Czech Republic's sustainable development strategy. Ecological Indicators, 17, 46-57.

Hwang, C. L., Yoon, K. (1981). Multiple attribute decision making - methods and applications. A state of the art survey. Springer Verlag, Berlin, Heidelberg, New York.

Ibrahim, F. I., Omar, D., Hanita, N., Mohamad, N. (2015). Theoretical Review on Sustainable City Indicators in Malaysia. Procedia - Social and Behavioral Sciences, 202, 322-329. http://dx.doi.org/10.1016/j.sbspro.2015.08.236

Kevin, F. R. L. (2007). Evaluating environmental sustainability: an integration of multiplecriteria decision-making and Fuzzy logic. Environmental Management, 39, 721-736.

Khalili, N. R., Duecker, S. (2013). Application of multi-criteria decision analysis in design of sustainable environmental management system framework. Journal of Cleaner Production, 47, 188-198.

Kondyli, J. (2010). Measurement and evaluation of sustainable development - a composite indicator for the islands of the North Aegean region, Greece. Environmental Impact Assessment Review, 30, 347-356.

Lapinskienė, G., Peleckis, K., Nedelko, Z. (2017). Testing environmental Kuznets curve hypothesis: the role of enterprise's sustainability and other factors on GHG in European countries. Journal of Business Economics and Management, 18(1), 54-67. http://dx.doi.org/10.3846/16111699.2016.1249401

Leksin, V. N., Porfiryev, B. N. (2016). Evaluation of the effectiveness of government programs of socioeconomic development of regions of Russia. Studies on Russian Economic Development, 27(4), 418-428. http://dx.doi.org/10.1134/S1075700716040109

Mardani, A., Jusoh, A., Nor, K. M. D., Khalifah, Z., Zakwan, N., Valipour, A. (2015). Multiple criteria decision-making techniques and their applications - a review of the literature from 2000 to 2014. Economic Research-Ekonomska Istrazivanja, 28(1), 516-571. http://dx.doi.org/10.1080/1331677x.2015.1075139. 
Pintér, L., Hardi, P., Martinuzzi, A., Halla, J. (2012). Bellagio STAMP: Principles for sustainability assessment and measurement. Ecological Indicators, 17, 20-28. http://dx.doi.org/10.1016/j.ecolind.2011.07.001.

Rajnoha, R., Lesníková, P. (2016). Strategic Performance Management System and Corporate Sustainability Concept - Specific Parametres in Slovak Enterprises. Journal of Competitiveness, 8(3), 107-124. http://dx.doi.org/10.7441/joc.2016.03.07.

Suna, X., Liub, X., Lia, F., Taoa, Y., Songa, Y. (2015). Comprehensive evaluation of different scale cities' sustainable development for economy, society, and ecological infrastructure in China. Journal of Cleaner Production 2015: 1-9. http://dx.doi.org/10.1016/j.jclepro.2015.09.002

Wallis, A. M., Graymore, M. L. M., Richards, A. J. (2011). Significance of environment in the assessment of sustainable development: The case for south west Victoria. Ecological Economics, 70(4), 595-605. http://dx.doi.org/10.1016/j.ecolecon.2010.11.010.

Zavadskas, E. K., Turskis, Z., Kildiene, S. (2014). State of Art Surveys of Overviews on MCDM/MADM Methods. Technological and Economic Development of Economy, 20(1), 165-179. http://dx.doi.org/10.3846/20294913.2014.892037.

Zhou, J., Xiao, H., Shang, J., Zhang, X. (2007). Assessment of sustainable development system in Suihua City, China, Chinese. Geographical Science, 17(4), 304-310. 